\title{
Author Correction: Multiplexed heritable gene editing using RNA viruses and mobile single guide RNAs
}

Evan E. Ellison, Ugrappa Nagalakshmi, Maria Elena Gamo, Pin-jui Huang, Savithramma Dinesh-Kumar and

Daniel F. Voytas (iD

Correction to: Nature Plants https://doi.org/10.1038/s41477-020-0670-y, published online 1 June 2020.

In the version of this Brief Communication originally published, in Extended Data Fig. 7, panels $\mathrm{c}$ and $\mathrm{d}$ mistakenly repeated the gel image shown in panel $b$. The original results and conclusions are unaffected by this error. All online versions of this Brief Communication have been corrected.

Published online: 16 December 2020

https://doi.org/10.1038/s41477-020-00837-2

(C) The Author(s), under exclusive licence to Springer Nature Limited 2020 